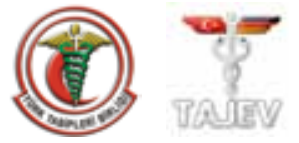

\title{
Recurrence of endometriosis; risk factors, mechanisms and biomarkers; review of the literature
}

\author{
Endometriozis rekürrensi; risk faktörleri, mekanizması ve biyomarkerlar; literatürün \\ gözden geçirilmesi \\ Ilker Selçuk' ${ }^{1}$ Gürkan Bozdağ \\ ${ }^{\prime}$ Department of Obstetrics and Gynecology, Hacettepe University Faculty of Medicine, Ankara, Turkey \\ ${ }^{2}$ Department of Obstetrics and Gynecology, Reproductive Endocrinology and Infertility Unit, Hacettepe University \\ Faculty of Medicine, Ankara, Turkey
}

\section{Abstract}

Endometriosis has a wide clinical spectrum and induces a chronic inflammatory process. The incidence of endometriosis in women with dysmenorrhoea is up to $40-60 \%$, whereas in women with subfertility is up to $20-30 \%$. Recurrence of endometriosis varies greatly among different studies. The overall recurrence rates range between 6 to $67 \%$ according to the criteria that are taken into consideration. Which of the various reasons is more predictive for recurrence is still unclear and controversial. The main aim of post-operative medical treatment is suppressing ovarian activity leading to atrophy of endometriotic lesions. The success of treatment depends on the resorption of all residual visible lesions and the eradication of microscopic implants. The recurrent lesions might originate from residual lesions or from de novo cells. Determining risk factors for recurrence may allow the identification of subgroups at risk for disease control. Potential biomarkers for recurrence could also maintain targeted therapy.

(J Turkish-German Gynecol Assoc 2013; 14: 98-103)

Key words: Endometriosis, recurrence, endometrioma, cystectomy Received: 23 January, 2013

Accepted: 26 March, 2013

\section{Özet}

Endometriozis geniş bir klinik spektruma sahiptir ve kronik inflamatuvar bir süreç oluşturur. Dismenoresi olan kadınlarda endometriozis insidansı \%40-60 iken, subfertil kadınlarda \%20-30 arasındadır. endometriozis rekürrensi değişik çalışmalarda farklı sonuçlar sergiler. Dikkate alınan kritere göre rekürrens oranı \%6 ile 67 arasında değişir. Rekürrens için birçok farklı nedenden hangisinin daha prediktif olduğu kesin değildir ve tartışmalıdır. Post operatif medikal tedavinin amacı ise overyan aktiviteyi suprese etmektir ve böylece endometriotik lezyonlarda atrofi sağlanır. Tedavinin başarısı tüm görülebilir rezidüel lezyonların ve mikroskobik implantların eradikasyonuna bağlıdır. Rekürren lezyonlar rezidüel yapılardan veya de novo hücrelerden kaynaklanabilir. Rekürrens için risk faktörlerini bilmek hastalığın kontrolü için subgrupların tanınmasını sağlar. Rekürrens açısından anlamlı potansiyel biyomarkerlar ise hedeflenmiş tedavinin temelini oluşturur.

(J Turkish-German Gynecol Assoc 2013; 14: 98-103)

Anahtar kelimeler: Endometriozis, rekürrens, endometrioma, kistektomi

Geliş Tarihi: 23 Ocak 2013

Kabul Tarihi: 26 Mart 2013

\section{Introduction}

Endometriosis is the presence of endometrial tissue with glands and stroma outside the uterus. Although endometriosis is a benign disease, its clinical spectrum varies widely, independent from its severity; endometriosis induces a chronic inflammatory process (1). It is hard to know the exact prevalence of endometriosis because surgery is needed for accurate diagnosis and asymptomatic patients may decrease the prevalence (2). However, according to the available literature, the incidence of endometriosis in women with dysmenorrhoea is approximately $40-60 \%$, whereas in women with subfertility it is up to $20-30 \%$ (3). Surgery is widely used for endometriosis treatment, but a significant risk of recurrence and unsolved symptoms make the disease the third most common cause of hospitalisation in the United States (4).

\section{Recurrence rates}

Endometriosis is a distinct entity that has an important role on morbidity and financial cost. Recurrence is frequently seen in patients with endometriosis and varies greatly among different studies. The overall recurrence rates range between 6 to $67 \%$ according to the criteria that are taken into consideration $(5,6)$. The discrepancy in the recurrence rate of endometriosis depends on a number of issues. Initially, the definition that was used for recurrence presents variations among studies; it might be expressed as pelvic pain described by the patient (dysmenorrhoea, dyspareunia) or clinical criteria (pelvic mass, nodulations on examination or imaging) or persistence in the situation of infertility. In a study by Vignali et al. (7) the reported recurrence rates for pain in 3- and 5-year periods were 20.5 and $43.5 \%$, respectively. The clinical recurrence rates for those periods were 9 and $28 \%$, respectively 
(7). Fedele et al. (8) reported the rate of recurrence for dysmenorrhoea as almost $30 \%$ after the end of a one-year period following laparoscopic surgery. Exacoustos et al. (9) defined recurrence as cysts with a diameter of more than $10 \mathrm{~mm}$ and found that pain was a realistic determinant factor for surgery, and that $76 \%$ of patients who had a recurrence suffered from pain-related symptoms. The recurrence rates for pain and painrelated symptoms are higher than the clinical recurrence rates detected by sonographic findings (10). Secondly, the duration of follow-up period after surgery influences the rate of recurrence, as expected. It has also been reported that the average two-year recurrence rate is $19.1 \%$ (from 23 studies), and the five-year recurrence rate ranges between 20.5 and $43.5 \%$ (10). Busacca et al. evaluated 144 recurrences of endometriosis from 1106 women diagnosed with endometriosis and found four-year recurrence rates as 24.6, 17.8, 30.6 and $23.7 \%$ for ovarian, peritoneal, deep ovarian and peritoneal endometriosis, respectively. The rates of recurrence increased as time passed after surgery and the 8-year recurrence rates were 42, 24.1, 43.4 and $30.9 \%$, respectively (11). Parazzini et al. (12) reported that the two-year recurrence rates for stage I and II endometriosis as $5.7 \%$, whereas it was $14.3 \%$ for stage III and IV endometriosis.

\section{Risk factors for recurrence}

Although various reasons have been proposed as risk factors, it is still unclear and there is a controversy surrounding for which is more predictive for recurrence. Li et al. (13) followed-up 285 patients for a minimum of 36 months for recurrence after conservative surgery for endometriosis and reported that a history of endometriosis surgery, bilateral pelvic involvement of endometriotic lesions, left-sided endometrioma, tenderness, nodularity at cul-de-sac, post-operative high revised American Fertility Society (rAFS) scores, and younger age were all risk factors for recurrence. Liu et al. (14) followed 710 patients after endometriosis surgery for an average of 22.4 months and defined the recurrence of endometrioma as the presence of ovarian cysts $3 \mathrm{~cm}$ in diameter for more than two consecutive menstrual cycles, and the recurrence of dysmenorrhoea as pain recurring after surgery with the severity score equal to or higher than that before surgery. They found that previous surgery, previous medication usage, younger age at surgery and total rAFS score were all risk factors for endometrioma recurrence; however, the total $\mathrm{AAFS}$ score was the only identified risk factor for dysmenorrhoea recurrence. For both recurrences, the hazard rate was constant in the first 28 -30 months after surgery, but the hazard rate increased dramatically after that period.

After the evaluation of 121 patients following conservative laparoscopic surgery, Ghezzi et al. (15) reported that the left sided endometriomas recur more frequently, whereas Jones and Sutton (16) found that bilateral cysts were more likely to recur than single cysts after the evaluation of 73 patients following consecutive laparoscopic ablation. Saleh and Tulandi (17) evaluated 231 patients after the laparoscopic excision of endometrioma cysts and found that the reoperation rate was higher in women with larger cysts; Koga et al. (18) also reported similar findings after following-up 224 patients post-operatively for a minimum of 2 years. Busacca et al. (5) followed-up 366 patients after laparoscopic endometrioma excision and reported that the advanced stage disease and previous surgery for endometriosis were two risk factors for recurrence and that the rate of recurrence increased with an extended follow-up period; they also found that the cyst recurrence was mostly associated with the pain recurrence. Porpora et al. (19) followed-up 166 patients after laparoscopic endometrioma cystectomy and found that prior surgery, pelvic adhesions and high rAFS score were all negative prognostic factors for recurrence. Fedele et al. (20) evaluated 47 symptomatic bladder endometriosis patients and found that the radicality of surgery was important for recurrence. Vignali et al. (7) reported that the completeness of the first surgery was a prognostic factor for recurrence after a 12 month follow-up period in 115 symptomatic patients who were operated upon for deep infiltrating endometriosis. Parazzini et al. (12) reported that the advanced stage disease at initial surgery had a higher recurrence rate and Busacca et al. (11) showed deep endometriosis, younger age, stage 3 or 4 disease and time passed after surgery were all risk factors for recurrence.

Pregnancy after surgery has been stated as a protective factor for recurrence by many studies. Pregnancy may suppress the activation and growth of endometriotic lesions and also inflammation caused by endometriotic lesions with regard to the increased progesterone levels (10). Table 1 shows the risk factors for recurrence.

\section{Preoperative medical therapy}

Preoperative medical therapy before surgery in endometriosis may increase the risk of recurrence. Koga et al. (18) followedup 224 patients for a minimum of 2 years post-operatively after laparoscopic ovarian endometrioma excision. They did not routinely administer pre- or post-operative medical treatment; this was only used because of the special needs of patients. 65 patients continued their medical treatment until the surgery and the average pre-operative medical treatment duration was 9.7 months. They concluded that the previous medical treatment for endometriosis caused significantly higher recurrence rates (18). That may be as a result of the endometriotic lesions being masked during the surgery because of the previous usage of medication. Moreover, medical treatment may alter some genomic processes of endometriotic lesions, and suppress normal eukaryotic cells. This may lead to an increase in dyskaryotic cells in the endometriotic implants by negative selection (21). Muzii et al. (22) also reported that pre-operative Gonadotropin Releasing Hormone (GnRH) agonist treatment did not provide any surgical improvement and did not affect recurrence rates.

\section{Postoperative medication and endometriosis recurrence}

Endometriosis is an oestrogen-dependent chronic inflammatory disease and an increased estrogenic effect on endometriotic tissues may aggravate the disease by genetic variations (23). The main aim of post-operative medical treatment is to suppress ovarian activity and that result in atrophy of endometriotic lesions. The success of treatment depends on the application of medical treatment after the resorption of all residual visible lesions and the eradication of the microscopic implants so that 
Table 1. Table shows the risk factors for recurrence with common sides

\begin{tabular}{|c|c|}
\hline Author, year & Risk factors \\
\hline Fedele, 2004 & \multirow[t]{4}{*}{ Younger age } \\
\hline Vignali, 2005 & \\
\hline Vercellini, 2006 & \\
\hline Liu, 2007 & \\
\hline Ghezzi, 2001 & \multirow[t]{2}{*}{ Laterality of lesions } \\
\hline Jones and Sutton, 2002 & \\
\hline Waller and Shaw, 1993 & \multirow{7}{*}{$\begin{array}{c}\text { rAFS stage } \\
\text { rAFS }>70 \\
\text { rAFS score }\end{array}$} \\
\hline Busacca, 1999 & \\
\hline Parazzini, 2005 & \\
\hline Abbott, 2003 & \\
\hline $\mathrm{Li}, 2005$ & \\
\hline Kikuchi, 2006 & \\
\hline Liu, 2007 & \\
\hline Saleh and Tulandi, 1999 & \multirow[t]{2}{*}{ Size of cyst } \\
\hline Koga, 2006 & \\
\hline Renner, 2010 & High preoperative pain \\
\hline Bulletti, 2001 & \multirow[t]{3}{*}{ Absence of pregnancy } \\
\hline Fedele, 2004 & \\
\hline $\mathrm{Li}, 2005$ & \\
\hline Koga, 2006 & \multirow[t]{2}{*}{ Previous medical treatment } \\
\hline Liu, 2007 & \\
\hline Vignali, 2005 & \multirow{2}{*}{$\begin{array}{c}\text { Completeness of the first surgery } \\
\text { Extend of surgical excision }\end{array}$} \\
\hline Fedele, 200 & \\
\hline $\mathrm{Li}, 2005$ & Painful nodule \\
\hline
\end{tabular}

the recurrence of the disease could be minimised and the pain free period could be maintained $(24,25)$.

Non-steroidal anti inflammatory drugs (NSAIDs) may decrease the severity of pain, but it is difficult to say whether they have a role on recurrence rates in comparison to placebo (26). In a review by Cochrane, NSAIDs were used for pain in endometriosis, but the existing data are inadequate to say that they are effective for the treatment of pain caused by endometriosis and there is no significant difference in pain relief between types of NSAIDs (26).

Telimaa et al. (27) described that medroxyprogesterone acetate and danazol reduce pelvic pain scores more effectively than placebo when used postoperatively, but this treatment has more valuable results when used for at least six months. Morgante et al. (6) reported that low-dose danazol $(100 \mathrm{mg} / \mathrm{d}$ for six months) and GnRH agonist treatment for six months postoperatively reduce pelvic pain incidence when compared with women not taking a therapy. Despite these findings, Bianchi et al. stated that there was not a significant role of danazol on postoperative recurrence rates when $600 \mathrm{mg} /$ day was used for 3 months, and found no difference on recurrence rates between two groups taking danazol or not, with a ratio of $26 \%$ and $34 \%$, respectively (28). The difference between the two studies might be related to the duration of treatment.

GnRH agonists are also used in the treatment of endometriosis after surgery (29). When compared with non users and placebo, the administration of GnRH agonists for 6 months after surgery reduces pain significantly at the 12 and 24 month follow-ups (30). Despite that study, the usage of GnRH agonists for 3 months had no effect on the pain free period in stage III/IV endometriosis (31). Jee et al. (32) reported that although postoperative $\mathrm{GnRH}$ agonist treatment did not reduce the objective disease recurrence in stage III/IV disease, the use of GnRH agonists delays the time to recurrence.

Oral contraceptive pills (OCP) have an important role on both recurrence rates and pain relief by the theory of ovarian inactivation, inhibition of proliferation on endometriotic lesions and also by decreasing retrograde menstruation $(33,34)$. Muzii et al. (34) evaluated patients who were taking low dose cyclic oral contraceptives compared to non-users after laparoscopic ovarian endometrioma excision and reported a prospective randomised controlled trial (RCT); results showed that recurrence rates were lower for the group who were using low dose cyclic oral contraceptives at the end of first year, but that the 24 and 36 month recurrence rates did not significantly differ between two groups. Koga et al. (18) also stated that the longterm recurrence rates did not significantly change in response to post-operative medical therapy.

Vercellini et al. (35) compared two groups: continuous OCP users post-operatively and those who had never used OCP; they found that continuous OCP users had a significantly reduced risk of recurrence which depended on the length of usage. There may be differences between the continuous and cyclic usage of OCP, especially from the theory that cyclic usage causes intermittent menstrual flow, which enforces the endometriotic lesions (36). Seracchioli et al. (33) reported that continuous or cyclic usage of OCP produced significantly better outcomes for recurrence when compared with the non-user group; however, there was no statistical difference between continuous and cyclic users. The continuous OCP usage might be initiated instead of cyclic treatment in the first step or scheduled if cyclic treatment fails to provide pain relief (37).

Levonorgestrel causes endometrial glandular atrophy, downregulation of endometrial cell proliferation, an increase in apoptosis and an anti-inflammatory and immunomodulatory effect. This causes amenorrhea in most patients, and also leads to a relief in pain related to the menstrual period (38). In 2003, Vercellini et al. (39) performed a randomised controlled trial, and reported that the insertion of a levonorgestrel-in utero device (LNG-IUD) reduces the recurrence risk after one year when compared with patients who are expectantly observed after surgery for endometriosis. Bayoglu et al. (40) compared LNG-IUD and GnRH agonists in a prospective randomised controlled study and found no significant difference regarding chronic pelvic pain associated with endometriosis after the short and medium duration of follow-up.

From this point of view, it is important to choose the treatment according to the side effects of the administered treatment and the patient's characteristics. 


\section{Causes of recurrence}

There are several studies that aim to investigate the cause of recurrence in endometriosis. The analytical determinants suggest that some subgroups with similar characteristics have high recurrence rates (14). Liu et al. (14) reported that the rate for disease recurrence is constant approximately for the first 30 months after surgery; however, the risk increases dramatically after that period, which highlights the importance of the length of follow-up period in the reported studies.

Mainly, the recurrent lesions might originate from residual lesions or alternatively from de novo cells coming through retrograde bleeding. Several studies demonstrate that the recurrence risk increases if the lesions are not completely removed during the initial surgery and tend to arise in the same location $(9,10)$. Of note, laparatomy versus laparoscopy shows comparable performance regarding the recurrence of dysmenorrhoea and pelvic pain; however, dyspareunia was higher in the laparatomy group and in those patients needing a new operation (41). The pregnancy rate also did not show a significant difference between two groups at the end of 24 months (41). For the treatment of endometrioma, excisional surgery for endometrioma was shown to be better than drainage and ablation, both for the recurrence of endometrioma, pain symptoms and fertility outcome (42). Of interest, Carmona et al. (43) reported that laser ablation resulted in higher and earlier recurrence rates when compared with endometrioma cystectomy. Fedele et al. (44) reported that the result of recurrence after repetitive laparoscopy was similar to that after the first surgery.

Lymph node involvement and lymphovascular invasion could also be responsible for recurrence, particularly in deep infiltrating endometriosis (45). Deep endometriosis also has a higher recurrence rate, which increases with time after first-line surgery. Although the radicality of the operation improves fertility outcome and reduces recurrence rates (11), a history of prior surgery and the presence of adhesions are negative prognostic factors for recurrence (19).

Approximately $10-18 \%$ of hysterectomies are performed as a result of chronic pelvic pain (46). Some studies reported endometriosis recurrence and the need for an additional surgery even after hysterectomy and bilateral salpingo-oophorectomy. Recurrent symptoms may occur in approximately $10 \%$ of patients after definitive surgery (47). Fedele et al. (48) reported that radical hysterectomy and removing infiltrating lesions achieves a better outcome and relief in symptoms when compared with conventional hysterectomy. Shakiba et al. (49) reported that the preservation of ovaries at hysterectomy increases the risk of reoperation for endometriosis-related symptoms.

The immunological factors might also play a role on the recurrence of endometriosis. The higher existence of CD15a positive Natural Killer cells in both peritoneal fluid and peripheral blood in women with endometriosis have been previously shown (50). Of interest, even after treatment with surgery or medical treatment, they do not decrease, which might cause the maintenance of an inflammatory environment for recurrence (50). The oestrogen receptor polymorphism, oestrogen receptor alpha-Pvull, may also be related to recurrence (51). Even in heterogeneous polymorphisms, the risk of recurrence increases according to the wild type.

\section{Biomarkers for recurrence}

Knowing risk factors for recurrence may allow subgroups to be identified who are at risk of recurrence. On the other hand, considering the mechanisms related to recurrence can protect the patient from unnecessary interventions and select the special treatment modality on the basis of patient characteristics (10). Since endometriosis is an oestrogen-dependent disease, the first candidate for a biomarker is the mechanism related to it. To recall the basic principles, oestrogen receptors (ER) exist in two forms, ER-alpha and ER-beta, which exhibit an E-binding domain and a DNA-binding domain. Luisi et al. reported that the ER-alpha gene polymorphism is more associated with recurrence, especially if Pvull ER-alpha gene homozygosity is detected (51). In accordance with that, women with the PP ER-alpha genotype have higher bone mineral density and a higher risk of undergoing premenopausal hysterectomy due to leiomyoma than other genotypes (52).

Cyclooxygenase-2 (COX-2) is a rate limiting enzyme of prostoglandin (PG) synthesis and plays a crucial role in the inflammation and proliferation of endometriotic lesions (53). It has been reported that in the peritoneal fluid of infertile women with endometriosis, the concentration of PGs are increased and abnormal levels of peritoneal PGs also cause adverse effects on fertilisation, implantation and embryonic growth (54). Overexpression of COX-2 is correlated with the intensity of dysmenorrhoea (55), and non-menstrual chronic pelvic pain in women with endometriosis (56). Yuan et al. (53) evaluated 109 patients for recurrence who had histologically confirmed endometriosis from previous surgery. COX-2 expression in endometrioma tissue samples was evaluated by immunohistochemistry and 53 patients were found to have recurrence, while the remaining 56 did not. They showed a significantly higher level of COX-2 staining in the recurrent group. In other words, over-expression of COX-2 causes more frequent recurrence, and COX-2 expression level, the previous use of medication and the presence of adhesions are three important risk factors for recurrence (53). Nuclear factor-kappa B (NF-kB) is a dimeric transcription factor that promotes the expression of more than 150 genes involved in cellular processes (57). p50, p52, p65, c-Rel and RelB are members of the NF-kB family. These all take part in DNA binding and regulation. A variety of genes are regulated by NF-kB, like genes for immune response, inflammatory processes, cell adhesion, proliferation and apoptosis (58). In vitro studies have shown that TNF-alpha and IL-1 alpha stimulation induce IL-6 and leukaemia inhibitory factor (LIF) production in endometrial epithelial cells, and that treatment with NF-kB inhibitor suppresses TNF-alpha or IL-1 alpha induced IL-6 and LIF production (59). NF-kB inactivation occurs through progesterone receptors (PRs). In the endometrium, there is a dynamic challenge with NF-kB activation and PR-B expression (60). Oxidants and cytokines are inducers of NF-kB activation, which in turn causes the proliferation of endometriotic cells. Therefore, NF-kB seems to have a pivotal role on the pathogenesis of endometriosis (58). Potentially, NF-kB is a 
promising biomarker to identify patients with a high risk of recurrence in endometriosis. Shen et al. (61) evaluated 109 patients who had undergone previous endometriosis surgery and had a histologically confirmed endometriosis. 53 of these patients had recurrence within 30 months of surgery, whereas the remaining 56 did not experience recurrence at least 32 months after the surgery. The patient groups were similar in age, rAFS stage, menstrual phase and other variables, except for the previous use of endometriosis-related medication. The patients' archived, formalin-fixed, paraffin-embedded tissue blocks were immunohistochemically stained for the progesterone receptor isoform B (PR-B) and nuclear factor kappaB p65 (NF-kB p65) subunit. The immunoreactivity of NF-kB p65 subunit was significantly higher in the recurrent group, whereas PR-B immunoreactivity was significantly higher in the non-recurrent group. The correlation between staining scores of NF-KB p65 subunit and COX-2 were also highly parallel. Therefore, increased NF-KB p65 immunoreactivity in relation with the decreased PR-B immunoreactivity constitutes a good biomarker for the recurrence of ovarian endometrioma, with both sensitivity and specificity ranges showing a minimum of $80 \%$. They eclipsed the prediction power of COX-2 after regression model (61).

\section{Conclusion}

It is difficult to completely eliminate the risk of endometriosis recurrence. Various risk factors have been suggested for recurrence in the literature and these are both patient- and surgeondependent. According to the risk factor and the follow-up period, the recurrence rates may also alter. Finding an ideal biomarker may clarify the recurrence process, so that an individualised treatment can be maintained.

Ethics Committee Approval: N/A

Informed Consent: N/A

Peer-review: Externally peer-reviewed.

Author contributions - I.S., G.B.; Concept - G.B.; Design G.B.; Supervision - G.B.; Resource - I.S., G.B.; Materials I.S., G.B.; Data Collection\&/or Processing - I.S.; Analysis\&/or Interpretation - I.S., G.B.; Literature Search - I.S.; Writing - I.S., G.B.; Critical Reviews - G.B.

Conflict of Interest: No conflict of interest was declared by the authors.

Financial Disclosure: No financial disclosure was declared by the authors.

\section{References}

1. Kennedy S, Bergqvist A, Chapron C, D'Hooghe T, Dunselman G, Greb $\mathrm{R}$, et al. ESHRE guideline for the diagnosis and treatment of endometriosis. Hum Reprod 2005; 20: 2698-704. [CrossRef]

2. Viganò P, Parazzini F, Somigliana E, Vercellini P. Endometriosis: epidemiology and aetiological factors. Best Pract Res Clin Obstet Gynaecol 2004; 18: 177-200. [CrossRef]
3. Farquhar C. Endometriosis. BMJ 2007; 334: 249-53. [CrossRef]

4. Velebil P, Wingo PA, Xia Z, Wilcox LS, Peterson HB. Rate of hospitalization for gynecologic disorders among reproductive-age women in the United States. Obstet Gynecol 1995; 86: 764-9. [CrossRef]

5. Busacca M, Marana R, Caruana P, Candiani M, Muzii L, Calia C, et al. Recurrence of ovarian endometrioma after laparoscopic excision. Am J Obstet Gynecol 1999; 180: 519-23. [CrossRef]

6. Morgante G, Ditto A, La Marca A, De Leo V. Low-dose danazol after combined surgical and medical therapy reduces the incidence of pelvic pain in women with moderate and severe endometriosis. Hum Reprod 1999; 14: 2371-4. [CrossRef]

7. Vignali M, Bianchi S, Candiani M, Spadaccini G, Oggioni G, Busacca M. Surgical treatment of deep endometriosis and risk of recurrence. J Minim Invasive Gynecol 2005; 12: 508-13. [CrossRef]

8. Fedele L, Bianchi S, Zanconato G, Bettoni G, Gotsch F. Long-term follow-up after conservative surgery for rectovaginal endometriosis. Am J Obstet Gynecol 2004; 190: 1020-4. [CrossRef]

9. Exacoustos C, Zupi E, Amadio A, Amoroso C, Szabolcs B, Romanini $\mathrm{ME}$, et al. Recurrence of endometriomas after laparoscopic removal: sonographic and clinical follow-up and indication for second surgery. J Minim Invasive Gynecol 2006; 13: 281-8. [CrossRef]

10. Guo SW. Recurrence of endometriosis and its control. Hum Reprod Update 2009; 15: 441-61. [CrossRef]

11. Busacca M, Chiaffarino F, Candiani M, Vignali M, Bertulessi C, Oggioni G, et al. Determinants of long-term clinically detected recurrence rates of deep, ovarian, and pelvic endometriosis. Am J Obstet Gynecol 2006; 195: 426-32. [CrossRef]

12. Parazzini F, Bertulessi C, Pasini A, Rosati M, Di Stefano F, Shonauer S, et al. Determinants of short term recurrence rate of endometriosis. Eur J Obstet Gynecol Reprod Biol 2005; 121: 216-9. [CrossRef]

13. Li HJ, Leng JH, Lang JH, Wang HL, Liu ZF, Sun DW, et al. Correlative factors analysis of recurrence of endometriosis after conservative surgery. Zhonghua Fu Chan Ke Za Zhi 2005; 40: 13-6.

14. Liu X, Yuan L, Shen F, Zhu Z, Jiang H, Guo SW. Patterns of and risk factors for recurrence in women with ovarian endometriomas. Obstet Gynecol 2007; 109: 1411-20. [CrossRef]

15. Ghezzi F, Beretta P, Franchi M, Parissis M, Bolis P. Recurrence of ovarian endometriosis and anatomical location of the primary lesion. Fertil Steril 2001; 75: 136-40. [CrossRef]

16. Jones KD, Sutton CJ. Recurrence of chocolate cysts after laparoscopic ablation. J Am Assoc Gynecol Laparosc 2002; 9: 315-20. [CrossRef]

17. Saleh A, Tulandi T. Reoperation after laparoscopic treatment of ovarian endometriomas by excision and by fenestration. Fertil Steril 1999; 72: 322-4. [CrossRef]

18. Koga K, Takemura Y, Osuga Y, Yoshino O, Hirota Y, Hirata T, et al. Recurrence of ovarian endometrioma after laparoscopic excision. Hum Reprod 2006; 21: 2171-4.[CrossRef]

19. Porpora MG, Pallante D, Ferro A, Crisafi B, Bellati F, Benedetti Panici $P$. Pain and ovarian endometrioma recurrence after laparoscopic treatment of endometriosis: a long-term prospective study. Fertil Steril 2010; 93: 716-21. [CrossRef]

20. Fedele L, Bianchi S, Zanconato G, Bergamini V, Berlanda N, Carmignani L. Long-term follow-up after conservative surgery for bladder endometriosis. Fertil Steril 2005; 83: 1729-33. [CrossRef]

21. Blumenfeld $Z$. Hormonal suppressive therapy for endometriosis may not improve patient health. Fertil Steril 2004; 81: 487-92. [CrossRef]

22. Muzii L, Marana R, Caruana P, Mancuso S. The impact of preoperative gonadotropin-releasing hormone agonist treatment on laparoscopic excision of ovarian endometriotic cysts. Fertil Steril 1996; 65: 1235-7.

23. Augoulea A, Alexandrou A, Creatsa M, Vrachnis N, Lambrinoudaki I. Pathogenesis of endometriosis: the role of genetics, inflammation and oxidative stress. Arch Gynecol Obstet 2012; 286: 99-103. [CrossRef] 
24. Vercellini P, Frontino G, De Giorgi O, Pietropaolo G, Pasin R, Crosignani PG. Endometriosis: preoperative and postoperative medical treatment. Obstet Gynecol Clin North Am 2003; 30: 163-80. [CrossRef]

25. ACOG Committee on Practice Bulletins--Gynecology. ACOG Practice Bulletin No. 11: Medical management of endometriosis. Obstet Gynecol 1999; 94: 1-14.

26. Allen C, Hopewell S, Prentice A. Non-steroidal anti-inflammatory drugs for pain in women with endometriosis. Cochrane Database Syst Rev 2005: CD004753.

27. Telimaa S, Rönnberg L, Kauppila A. Placebo-controlled comparison of danazol and high-dose medroxyprogesterone acetate in the treatment of endometriosis after conservative surgery. Gynecol Endocrinol 1987; 1: 363-71. [CrossRef]

28. Bianchi S, Busacca M, Agnoli B, Candiani M, Calia C, Vignali M. Effects of 3 month therapy with danazol after laparoscopic surgery for stage III/IV endometriosis: a randomized study. Hum Reprod 1999; 14: 13357. [CrossRef]

29. Brown J, Pan A, Hart RJ. Gonadotrophin-releasing hormone analogues for pain associated with endometriosis. Cochrane Database Syst Rev 2010: CD008475.

30. Vercellini P, Crosignani PG, Fadini R, Radici E, Belloni C, Sismondi P. A gonadotrophin-releasing hormone agonist compared with expectant management after conservative surgery for symptomatic endometriosis. Br J Obstet Gynaecol 1999; 106: 672-7. [CrossRef]

31. Busacca M, Somigliana E, Bianchi S, De Marinis S, Calia C, Candiani $\mathrm{M}$, et al. Post-operative $\mathrm{GnRH}$ analogue treatment after conservative surgery for symptomatic endometriosis stage III-IV: a randomized controlled trial. Hum Reprod 2001; 16: 2399-402.

32. Jee BC, Lee JY, Suh CS, Kim SH, Choi YM, Moon SY. Impact of GnRH agonist treatment on recurrence of ovarian endometriomas after conservative laparoscopic surgery. Fertil Steril 2009; 91: 40-5. [CrossRef]

33. Seracchioli R, Mabrouk M, Frascà C, Manuzzi L, Montanari G, Keramyda A, et al. Long-term cyclic and continuous oral contraceptive therapy and endometrioma recurrence: a randomized controlled trial. Fertil Steril 2010; 93: 52-6. [CrossRef]

34. Muzii L, Marana R, Caruana P, Catalano GF, Margutti F, Panici PB. Postoperative administration of monophasic combined oral contraceptives after laparoscopic treatment of ovarian endometriomas: a prospective, randomized trial. Am J Obstet Gynecol 2000; 183: 588-92. [CrossRef]

35. Vercellini P, Somigliana E, Daguati R, Vigano P, Meroni F, Crosignani PG. Postoperative oral contraceptive exposure and risk of endometrioma recurrence. Am J Obstet Gynecol 2008; 198: 504 e1-5.

36. Crosignani P, Olive D, Bergqvist A, Luciano A. Advances in the management of endometriosis: an update for clinicians. Hum Reprod Update 2006; 12: 179-89. [CrossRef]

37. Vercellini P, Frontino G, De Giorgi O, Pietropaolo G, Pasin R, Crosignani PG. Continuous use of an oral contraceptive for endometriosis-associated recurrent dysmenorrhea that does not respond to a cyclic pill regimen. Fertility and Sterility 2003; 80: 560-3. [CrossRef]

38. Vercellini P, Viganò $\mathrm{P}$, Somigliana $\mathrm{E}$. The role of the levonorgestrelreleasing intrauterine device in the management of symptomatic endometriosis. Curr Opin Obstet Gynecol 2005; 17: p. 359-65. [CrossRef]

39. Vercellini P, Frontino G, De Giorgi O, Aimi G, Zaina B, Crosignani PG. Comparison of a levonorgestrel-releasing intrauterine device versus expectant management after conservative surgery for symptomatic endometriosis: a pilot study. Fertil Steril 2003; 80: 305-9. [CrossRef]

40. Bayoglu Tekin Y, Dilbaz B, Altinbas SK, Dilbaz S. Postoperative medical treatment of chronic pelvic pain related to severe endometriosis: levonorgestrel-releasing intrauterine system versus gonadotropinreleasing hormone analogue. Fertil Steril 2011; 95: 492-6. [CrossRef]

41. Busacca M, Fedele L, Bianchi S, Candiani M, Agnoli B, Raffaelli R, et al. Surgical treatment of recurrent endometriosis: laparotomy versus laparoscopy. Hum Reprod 1998; 13: 2271-4. [CrossRef]

42. Hart RJ, Hickey M, Maouris P, Buckett W. Excisional surgery versus ablative surgery for ovarian endometriomata. Cochrane Database Syst Rev 2008: CD004992.

43. Carmona F, Martínez-Zamora MA, Rabanal A, Martínez-Román S, Balasch J. Ovarian cystectomy versus laser vaporization in the treat- ment of ovarian endometriomas: a randomized clinical trial with a five-year follow-up. Fertil Steril 2011; 96: 251-4. [CrossRef]

44. Fedele L, Bianchi S, Zanconato G, Berlanda N, Raffaelli R, Fontana E. Laparoscopic excision of recurrent endometriomas: long-term outcome and comparison with primary surgery. Fertil Steril 2006; 85: 694-9. [CrossRef]

45. Randall GW, Gantt PA, Poe-Zeigler RL, Bergmann CA, Noel ME, Strawbridge WR, et al., Serum antiendometrial antibodies and diagnosis of endometriosis. Am J Reprod Immunol 2007; 58: 374-82. [CrossRef]

46. Carlson KJ, Miller BA, Fowler FJ Jr. The Maine Women's Health Study: I. Outcomes of hysterectomy. Obstet Gynecol 1994; 83: 556-65. [CrossRef]

47. Namnoum AB, Hickman TN, Goodman SB, Gehlbach DL, Rock JA. Incidence of symptom recurrence after hysterectomy for endometriosis. Fertil Steril 1995; 64: 898-902.

48. Fedele L, Bianchi S, Zanconato G, Berlanda N, Borruto F, Frontino G. Tailoring radicality in demolitive surgery for deeply infiltrating endometriosis. Am J Obstet Gynecol 2005; 193: 114-7. [CrossRef]

49. Shakiba K, Bena JF, McGill KM, Minger J, Falcone T. Surgical treatment of endometriosis: a 7-year follow-up on the requirement for further surgery. Obstet Gynecol 2008; 111: 1285-92. [CrossRef]

50. Maeda N, Izumiya C, Kusum T, Masumoto T, Yamashita C, Yamamoto $\mathrm{Y}$, et al. Killer inhibitory receptor CD158a overexpression among natural killer cells in women with endometriosis is undiminished by laparoscopic surgery and gonadotropin releasing hormone agonist treatment. Am J Reprod Immunol 2004; 51: 364-72. [CrossRef]

51. Luisi S, Galleri L, Marini F, Ambrosini G, Brandi ML, Petraglia F. Estrogen receptor gene polymorphisms are associated with recurrence of endometriosis. Fertil Steril 2006; 85: 764-6. [CrossRef]

52. Wang Z, Yoshida S, Negoro K, Kennedy S, Barlow D, Maruo T. Polymorphisms in the estrogen receptor beta gene but not estrogen receptor alpha gene affect the risk of developing endometriosis in a Japanese population. Fertil Steril 2004; 81: 1650-6. [CrossRef]

53. Yuan L, Shen F, Lu Y, Liu X, Guo SW. Cyclooxygenase-2 overexpression in ovarian endometriomas is associated with higher risk of recurrence. Fertil Steril 2009; 91: 1303-6. [CrossRef]

54. Sales KJ, Jabbour HN. Cyclooxygenase enzymes and prostaglandins in pathology of the endometrium. Reproduction 2003; 126: 559-67. [CrossRef]

55. Matsuzaki S, Canis M, Pouly JL, Wattiez A, Okamura K, Mage G. Cyclooxygenase-2 expression in deep endometriosis and matched eutopic endometrium. Fertil Steril 2004; 82: 1309-15. [CrossRef]

56. Buchweitz O, Staebler A, Wülfing P, Hauzman E, Greb R, Kiesel L. COX-2 overexpression in peritoneal lesions is correlated with nonmenstrual chronic pelvic pain. Eur J Obstet Gynecol Reprod Biol 2006; 124: 216-21. [CrossRef]

57. Kumar A, Takada Y, Boriek AM, Aggarwal BB. Nuclear factor-kappaB: its role in health and disease. J Mol Med (Berl) 2004; 82: 434-48. [CrossRef]

58. Guo SW. Nuclear factor-kappab (NF-kappaB): an unsuspected major culprit in the pathogenesis of endometriosis that is still at large? Gynecol Obstet Invest 2007; 63: 71-97. [CrossRef]

59. Laird SM, Tuckerman EM, Cork BA, Li TC. Expression of nuclear factor kappa B in human endometrium; role in the control of interleukin 6 and leukaemia inhibitory factor production. Mol Hum Reprod 2000; 6: 34-40. [CrossRef]

60. Davies S, Dai D, Feldman I, Pickett G, Leslie KK. Identification of a novel mechanism of NF-kappaB inactivation by progesterone through progesterone receptors in Hec50co poorly differentiated endometrial cancer cells: induction of A20 and ABIN-2. Gynecol Oncol 2004; 94: 463-70. [CrossRef]

61. Shen F, Wang Y, Lu Y, Yuan L, Liu X, Guo SW. Immunoreactivity of progesterone receptor isoform $B$ and nuclear factor kappa-B as biomarkers for recurrence of ovarian endometriomas. Am J Obstet Gynecol 2008; 199: 486.e1-10. 